\title{
Perspectiva InTERdisciplinar da TeOlogia no BRASIL: O debate epistemológico da Área de Ciências da Religião e Teologia
}

\author{
INTERDISCIPLINARY PERSPECTIVE OF THEOLOGY IN BRAZIL: \\ The epistemological debate of the Area of \\ Sciences of Religion and Theology
}

Alex Villas Boas *

\section{RESUMO}

O presente artigo pretende fazer uma breve reflexão sobre o desenvolvimento histórico da epistemologia teológica no Brasil, com ênfase na teologia católica, de acordo com as mudanças ocorridas nas condições da produção de conhecimento científico desde a modernidade, sobretudo, com o surgimento das Ciências da Religião. Tal proposta pretende situar tal debate epistemológico apontando alguns fatos históricos de maior relevância, a fim de captar as principais tendências. Com isso, pretende-se apresentar como se desenvolveu o perfil interdisciplinar da Teologia no Brasil, dentro do debate da Área de Ciências da Religião e Teologia, como caso sui generis, de uma via cooperativa e de perspectiva compartilhada entre as duas áreas de conhecimento.

Palavras-Chave: Epistemologia Teológica. Teologia e Ciência(s) da(s) Religião(s). Interdisciplinaridade.

\section{ABSTRACT}

The aim of this paper is to do a brief reflection on the historical development of theological epistemology in Brazil, with emphasis on Catholic theology, according to the changes occurring in the conditions of the production of scientific knowledge since the Modernity, above all, with the emergence of the Sciences of Religion. This proposal intends to situate this epistemological debate pointing out some historical facts of greater relevance in order to capture as main trends. Thus, it intends to present how the interdisciplinary character of Theology in Brazil, inside the Area of Science of Religion and Theology was developed, as a sui generis case, a cooperative pathway and a shared perspective between the two areas of knowledge.

Keywords: Theological epistemology. Theology and Science(s) of religion(s). Interdisciplinarity.

\section{INTRODUÇÃO}

Atualmente, a formação teológica no Brasil é oferecida por 206 cursos presenciais, que somados aos 388 polos na modalidade de Ensino à Distância [EaD], chega-se à cifra de 549 ofertas de cursos de graduação em Teologia reconhecidos pelo

\footnotetext{
* Pós-doutor em Teologia pela Pontifícia Universidade Gregoriana de Roma e doutor em Teologia Sistemática pela Pontifícia Universidade Católica do Rio de Janeiro. Atualmente é professor liv re docente na Pontifícia Universidade Católica do Paraná e coordenador do Programa de Pós-graduação em Teologia.E-mail: alex.boas@pucpr.br
} 
MEC, sem contar os institutos e seminários de diversas denominações, o que aumentaria ainda mais esse número. No que diz respeito à formação de docentes e pesquisadores pelo ingresso no mestrado e doutorado em Teologia, há 9 ofertas de Programas de Pós-Graduação em Teologia, concentrados majoritariamente na região Sul e Sudeste ${ }^{1}$.

Uma preocupação com esse crescimento nas últimas décadas é em que medida há uma cultura epistemológica que ofereça condições de um pensar teológico adequado aos desafios contemporâneos, uma vez que houve descontinuidades e rupturas epistemológicas ao longo da história da Teologia no Brasil, que talvez não tenham sido devidamente debatidos ou apropriados pela comunidade acadêmica. $\mathrm{O}$ indicativo de tal lacuna tem por base manifestações de alguns fenômenos religiosos sintomáticos e de grande repercussão no cenário social, cultural e político brasileiro, que parece sustentar uma nova forma de Teologia de Estado 34 , e que confirmam a revisão da afirmação dostoievskiana, em um mundo de jihadismos e devaneios ideológicos de grupos religiosos que ainda advogam supremacia, ou promovem manipulação de cenários políticos, com elementos de radicalismo e intolerância: "Se Deus existe, tudo é permitido" (ŽIŽEK, 2006, p. 114).

A proposta do presente trabalho é resgatar um breve histórico da formação teológica no Brasil, com maior ênfase na teológica católica, para identificar algumas tendências epistemológicas, motivadas pelo contexto cultural e religioso, em especial como o surgimento das Ciências da Religião, que se deu de modo peculiar no Brasil com o apoio da Teologia, configurando-se assim uma perspectiva interdisciplinar da Área de Ciências da Religião e Teologia, um debate epistemológico que já tem quase 50 anos. Em um primeiro momento se pretende apontar tais fatos históricos de maior

\footnotetext{
${ }^{1}$ BRASIL. Ministério da Educação. Cadastro e-MEC de Instituições e Cursos de Educação Superior, Brasília, MEC, 2007. Disponível em <http://emec.mec.gov.br/>. Acesso em 15 out. 2018; BRASIL. Ministério da Educação. CAPES - Coordenação de Aperfeiçoamento de Pessoal de Nível Superior. Plataforma Sucupira. Brasília: $\quad$ Fundação $\quad$ CAPES, $2014 . \quad$ Disponível $\quad$ em https://sucupira.capes.gov.br/sucupira/public/consultas/coleta/programa/quant itativos/quantitativoles.jsf?areaAv aliacao $=44 \&$ areaConhecimento $=71000003$ >. Acesso em 15 out. 2018. Vide Anexo.

${ }^{2}$ A Teologia de Estado aqui apresentada faz referências a utilização de um tipo de teologia chamado teodiceia, que opera como sociodiceia, uma apresentação de justificativas divinas para fatos históricos e decisões políticas (BOURDIEU, 1998, p. 58-59)

${ }^{3}$ MARTÍN, Maria. Deus derruba presidenta do Brasil: Deputados justificam seus votos em Deus, na moralidade e a família: o motivo real da votação é esquecido. E País, 19 abr. 2016. Disponível em: <http://brasil.elpais.com/brasil/2016/04/18/politica/1460935957_433496.html>. Acesso em 15 out. 2018.

${ }^{4}$ SOUSA PINTO, Ana Estela de. Nove entre dez brasileiros atribuem a Deus sucesso financeiro. Folha de São Paulo, 25 dez. 2016, Poder. Disponível em: <http://.folha.uol.com.br/poder/2016/12/1844383-nove-entre-dezbrasileiros-atribuem-a-deus-sucesso-financeiro.shtml>. Acesso em 15 out. 2018.
} 
relevância para a cultura epistemológica brasileira para, em um segundo momento, refletir sobre essa característica interdisciplinar do labor teológico em diálogo com as Ciências da Religião.

\section{BREVE CONTEXTUALIZAÇÃO HISTÓRICA DA FORMAÇÃO TEOLÓGICA NO BRASIL}

A formação teológica no Brasil remonta à própria história do país. Contudo, há momentos históricos precisos que influenciam novas tendências teológicas, e que evocá-los, brevemente, pode ajudar a melhor compreender os modelos de epistemologia teológica no Brasil.

\subsection{O surgimento da formação teológica no Brasil colônia}

A presença da formação teológica no Brasil remonta ao período do Brasil colonial (1500-1815). Já em 1553, o jesuíta Manoel da Nóbrega (1517-1570) fundou o Colégio dos Jesuítas da Bahia, em Salvador (1553-1759), onde o Pe. Antônio Vieira (1608-1697) iniciou seus primeiros estudos em 1614, e que mais tarde retorna para completar seus estudos de teologia e ser ordenado em 1634. Em 1638, Vieira foi nomeado professor de teologia no mesmo colégio. Em carta para a Cúria Geral da Companhia de Jesus, em 1626, Vieira relata 120 padres jesuítas, dos quais 31 eram professores, e havia 62 estudantes seguindo o plano de estudos do Ratio Studiorum (AZEVEDO, 1918, p. 33-71; VIEIRA, 1626, p. 77). A criação de colégios jesuítas ao longo de todo o território nacional tornou-se um dos principais fatores da formação teológica brasileira inicial. Seu modelo epistemológico, apesar de ser marcado pela escolástica tardia, incluía alguns "passos iniciais", de registros etnográficos e antropológicos, de uma tentativa de compreensão das religiões existentes no Brasil, porém sem a designação científica, somente elaborada posteriormente (MARQUES; ROCHA, 2007, p. 192), configurando-se assim, um primeiro exercício interdisciplinar no labor teológico, incomum para a época.

Em 1707, realizou-se no Brasil o I Sínodo Diocesano da Bahia, convocado por Dom Sebastião Monteiro da Vide, com a participação de jesuítas, franciscanos, agostinianos e carmelitas, tratando da fé católica e os desafios da colônia, revelando 
assim uma cultura teológica bastante viva (BESEN, 2002. p. 13; TORRESLONDOÑO, 2005, p. 275-282). Também é famosa a colaboração dos franciscanos com a formação teológica brasileira no período colonial com a casa de formação da Província Franciscana da Imaculada Conceição, no Convento de Santo Antônio do Rio de Janeiro, fundado em 1608, que chegou a possuir treze cadeiras de estudo de Teologia em 1776 (SANGENIS, 2006, p. 33-34).

\subsection{A influência jansenista na Teologia católica e o modelo apologético}

O ambiente de formação teológica brasileira, no caso da Teologia católica, entretanto, começa a mudar com a expulsão dos jesuítas em 1759, pois os Seminários Diocesanos vão se tornando um elemento chave para a presença do jansenismo no Brasil, como principal política de combate à mentalidade jesuíta, introduzida por Marques de Pombal (1699-1782) com vinda da Família Real ao Brasil (1808-1821). Como Secretário de Estado do Reino Unificado, aplicou as mesmas medidas de reeducação religiosa que utilizou em Portugal, impondo o Catecismo de Montepellier, muito utilizado pelos jansenistas, portador de uma antropologia negativa e que tanto via adultos quanto crianças como corrompidas pela "malícia completa", passando a ser utilizado na educação das escolas, por decreto imperial a partir de 1770 (ANJOS, 2016, p. 1032-1048).

Face a uma antropologia pessimista, a propaganda moralista e o legalismo passam a ser a tônica teológica empregada, que retroalimenta o papel da Igreja de disciplinadora moral em sua aliança com o Estado. O acento individualista do jansenismo, além de não oferecer críticas ao Estado, foi desenvolvendo com isso uma função econômica capitalista, em sua versão "plus spirituelle” do catolicismo, e que Bourdieu classificaria como sociodiceia, ou seja, como "justificação teórica para o fato de [alguns] serem privilegiados, uma “teodiceia dos seus privilégios" (BOURDIEU, 1998, p. 58-59, GROETHUYSEN, 1927, p. 31;46; VILLAS BOAS, 2017, p. 49-91).

Os seminários diocesanos, por sua vez, com a expulsão dos jesuítas e a restrição à expansão das Ordens Religiosas, olhadas desde então com desconfiança, passariam a integrar a rede de reconfiguração teológica, aplicando a pedagogia de Port Royal e a Teologia de Lyon, que tinha o Augustinus de Antoine Arnauld como referência para uma forte teologia da eleição e um rigorismo moral, bem como uma 
reticência em relação à filosofia. Tal expansão do movimento, que atinge a maioria do clero brasileiro, fora encampada pelos chamados Bispos reformadores no século XIX (MELO, 2014, p. 99).

A epistemologia teológica adotada pelo jansenismo é melhor formulada por Blaise Pascal (1623-1662), em sua Apologia da Religião Cristã, apontando para a insuficiência da filosofia, e consequentemente das luzes da razão para conduzir o homem a sua realização e a Deus, recuperando, assim, e radicalizando, um tema de Santo Agostinho na Vida Feliz. Há nessa posição de Pascal uma espécie de epistemologia especial da fé, tendo sua origem na interpretação da tensão entre teólogos e o racionalismo moderno, formulando um modelo epistemológico apologético, com privilégio da fé (PASCAL, 1858: posição 28736).

\subsection{A presença dos seminários de Teologia protestante no Brasil}

Ademais, a partir do século XIX, os seminários diocesanos católicos se deparavam com mais um novo desafio: a criação dos seminários protestantes no Brasil, que ampliava a percepção de perigo à fé.

O primeiro foi o Seminário Teológico da Corte no Rio de Janeiro, da Igreja Presbiteriana do Brasil em 1867, e transferido em 1907 para o Seminário Presbiteriano do Sul, em Campinas, seguido da criação do Seminário Metodista em 1890, em Juiz de Fora (MG), e depois, juntamente com a Faculdade de Teologia do Concílio Regional Sul de Passo Fundo (RS), foi unificada com nova sede em São Paulo, em 1938. Somente em 1970 é novamente realocada em São Bernardo do Campo (SP), como Instituto Metodista de Ensino Superior. Em 1902 e 1908 houve a criação, respectivamente, do Seminário Teológico Batista do Norte, em Recife (PE), e o Seminário Teológico Batista do Sul, no Rio de Janeiro (RJ). Em 1914, os Congregacionalistas, oriundos do Anglicanismo, abrem o Seminário Teológico da União, no Rio de Janeiro (RJ). Em 1921, em São Leopoldo (RS), é criado um curso de formação humanística de preparação para os estudos teológicos pelos Luteranos, e que em 1931 vira o Curso Pré-Teológico, que por fim, em 1946, cria a Faculdade de Teologia Evangélica ou também conhecida como Escola de Teologia. De 1940 a 1959 surgiram respectivamente o Seminário Teológico Batista do Paraná (1940), em Curitiba, o Seminário Batista do Nordeste (1942), na cidade de Triunfo (PE), depois 
transferido para Feira de Santana (1953). Também teve início as atividades da então chamada, Faculdade de Teologia do Colégio Batista Brasileiro (1957), em São Paulo (SP), e a Faculdade Batista de Brasília (1956), no Distrito Federal (MEC, 2014, p. 45).

Em menos de cem anos, o Brasil católico assistia à criação de pelo menos dez instituições de ensino teológico protestante, e teve como reação o início efetivo da Contrarreforma brasileira, no desenvolvimento de uma teologia católica brasileira dedicada a combater o protestantismo na primeira metade do século XX que, dado o contexto, se configura como um modelo epistemológico fundamentalmente voltado ao proselitismo (MENDONÇA, VELASQUES FILHO, 2002, p. 11-60).

Devido ao surgimento dos seminários protestantes e o espírito iluminista e positivista das ciências no Brasil, houve uma renovação da teologia escolástica de modo que preparasse o teólogo para combater os chamados “ inimigos da Igreja”, tendo por inspiração a Constituição Apostólica Deus Scienciarum Dominus, de 1931, que propunha uma reforma nos estudos teológicos e uma transição do modelo medieval de magister da baixa escolástica, em seu método acentuadamente especulativo, para assimilar a eruditio da nova scientia (BEA, 1941, p. 445-466). Nesse espírito, as Universidades eclesiásticas ou Pontifícias da Escola Romana desenvolverão uma recepção crítica e parcial da filosofia kantiana, como é o caso de Garrigou Lagrange (1877-1964), sendo o “tipo moderno", uma qualificação apologética que aporta a erudição científica. O ápice do projeto apologético neotomista da teologia católica oficial foi a criação das Pontifícias Universidades Católicas, como expressão de fidelidade ao Papa (todas com símbolos das chaves de Pedro e a Tiara Papal em seus respectivos brasões), e equipadas com um pensamento neotomista hegemônico para a defesa da fé católica e a ênfase na questão da verdade, como modo de desqualificar a pregação adversária. Resultou em um isolamento dos seminaristas do contato com essas "ideologias" perigosas, de modo que a teologia fora reservada para o clérigo, que era formado no século XX para pensar um modelo epistemológico do século XVI (SERBIN, 2008, p. 81).

Tal modelo epistemológico apologético na teologia católica brasileira vai perdurar até a segunda metade do século XX, e só começa a mudar após o Concílio Vaticano II. 


\section{$2.4 O$ modelo epistemológico de teologia contextual após o Concílio Vaticano II}

O desgaste do modelo metafísico tradicional e apologético após Auschwitz, no contexto da crise das Cristandades europeias, levou a diversos movimentos de renovação teológica (Movimento Bíblico, Renovação Litúrgica, Nouvelle théologie, Movimento Ecumênico...) que foram reconhecidos e reafirmados na Tradição Católica a partir do Concílio Vaticano II (1962-1965) como modelos alternativos à chamada Denzingertheologie, restrita à teologia de fórmulas, pois "uma coisa é o próprio depósito de fé ou as verdades e outra é o modo de enuncia-las, conservandose, contudo, o mesmo sentido [sensu] e significado [sententia]" (Gaudium et Spes, $62)$.

Os termos sensu e sententia remetem ao método teológico de Hugo de São Vitor (1096-1141), no século XII, que é resumido em uma fórmula célebre: littera, sensu, sententia. O método sugere que se apreenda o significado imediato da palavra (sensus), a partir da sua articulação literal (lettera), determinando a interpretação do conteúdo doutrinal (Didascalion, III, 9). Assim, a "lição" [lectio] se torna uma "questão" [questio], um tema a ser problematizado, criticado, aprofundado, revisitado até alcançar maior profundidade na pedagogia vitoriana, ou seja, de mero conteúdo se desdobra em uma questão problematizada que visa uma "compreensão mais profunda" [profundior intelligentia] (CHENU, 1983, p. 412).

Tal perspectiva emoldura uma proposta de método indutivo e o modelo epistemológico de uma teologia contextual, que inspira a elaboração de pelo menos quatro ramos da Teologia Latino Americana, na classificação de Juan Luís Scannone: 1) Teologia Pastoral, como práxis da libertação, presente sobretudo na atuação dos bispos latino americanos, sem necessariamente assumir uma mediação socioanalítica, mas desde uma perspectiva fundamentalmente "ético-antropológica"; 2) Teologia da Revolução, pensada desde a práxis de grupos revolucionários, que faz uso da análise marxista (materialismo histórico) e se apresenta como comprometida com a ação revolucionária, tendo como um dos referenciais o teólogo Hugo Assmann; 3) Teologia da Libertação, elaborada desde a práxis histórica, que por meio de uma mediação socioanalítica interpela uma hermenêutica teológica, que busca uma transformação estrutural da sociedade latino-americana, por meio de uma reflexão e 
uma práxis libertadora pastoral e política, criada inicialmente por Gustavo Gutierrez; e, por fim, 4) Teologia da Cultura ou Teología del Pueblo, pensada desde as identidades culturais dos povos latino-americanos, onde se situa o ramo argentino, e que apesar de não negar a mediação socioanalítica, privilegia o uso da mediação histórico cultural (SCANNONE, 1982, p. 19-29).

\subsection{O debate epistemológico da Teologia após o surgimento da Ciência da Religião}

Até meados do século XVIII, os estudos de religião eram praticamente de domínio exclusivo da Teologia. Contudo, a concepção de ciência moderna, marcada pela observação e análise de dados empíricos resultaram também no surgimento da Ciência da Religião na Alemanha [Religionswissenschaft], que nasce com tais pressupostos, para atender à demanda do saber de outras religiões, desde o contato estabelecido com os povos latino americanos, africanos e asiáticos, devido à expansão europeia ultramarina, como Portugal, Espanha, Holanda, França, Alemanha e Inglaterra, iniciado com Friedrich Max Müller (1823-1900). A Religionswissenschaft se afirmava negando a teologia do século XIX, ou seja, se configurava se distanciando cada vez mais do modo de proceder dos estudos teológicos e seus modelos apologéticos hegemônicos, a fim de que o cientista da religião fosse capaz de "absterse de pressupostos” e “"preconceitos' teológicos” (GRESCHAT, 2006, p. 155-160; HOLSTEN apud USARSKI, 2006, p. 64). Teve início, assim, um novo procedimento investigativo que foi gerando um acúmulo de capital de conhecimento, oriundos dos métodos de observação e validação empíricas da moderna concepção de ciência. Também, com uma perspectiva diferente de não demonização das demais religiões, ou tidas como inferiores à hegemonia cristã, reconhecendo nelas outras formas de civilização, sem um julgamento apriorístico, como faziam as teologias das religiões oficiais.

Contudo, diferente do surgimento da Ciência da Religião na Europa, que nasce como razão de recusa da Teologia, no Brasil sua emergência coincide com a consolidação do movimento de renovação teológica, e no caso católico, da oficialização dessa renovação via Concílio Vaticano II, e, portanto, de produção de uma teologia contextual, de onde emerge também as teologias latino-americanas e as 
teologias das religiões, que não somente apoiam como anseiam por estudos empíricos de religião, como é o caso da sociologia da religião, em relação à teologia da libertação, e da fenomenologia e da psicologia da religião, em relação as teologia das religiões.

Apesar do contexto político estar situado na separação entre Igreja e Estado, promulgada pela constituição de 1891, endossando o princípio da liberdade religiosa no Brasil desde a Constituição de 1824, é só com o novo clima “cultural” de abertura teológica na Igreja Católica que se favoreceu a leitura social da realidade religiosa brasileira, acentuadamente marcada pela diversidade de Igrejas protestantes, evangélicas, pentecostais, religiões afro, judaísmo, e a presença de religiões orientais, como budismo, hinduísmo e mesmo islã, presentes desde muito cedo, advindos quer seja por famílias migrantes, quer seja pelo tráfico de escravos africanos subsaarianos praticantes da religião muçulmana, entre outras.

No caso brasileiro, pode-se verificar uma abertura da comunidade acadêmica teológica brasileira, não somente para receber como também para apoiar o surgimento das Ciências da Religião (nomenclatura original) na Universidade Federal de Juiz de Fora (UFJF), a fim de se estudar o "fenômeno religioso em seus vários aspectos", sem excluir a teologia, mas inclusive " podendo ser ministrados cursos sobre e de Teologia” no âmbito das Ciências da Religião (Parecer No. 190/68, aprovado em 15 de março de 1968, Processo 733/67 - CFE). Não havia uma resistência à Teologia, mas sim a um modelo estritamente dogmático e clerical, com finalidades específicas de práticas religiosas, o que parecia ser naquele momento pouco viável para se atingir as metas do curso de "promoção do diálogo entre as grandes religiões”, sem excluir, contudo, uma reflexão mais crítica do cristianismo, denominado oficialmente na proposta do curso de Ciências da Religião como “religião que é servida pela UFJF”.

Com isso, o perfil do egresso se ampliava de uma finalidade exclusivamente pastoral, sem necessariamente excluí-las, para as funções de "professor de religião em estabelecimentos de ensino, orientador religioso-pastoral e técnico em assuntos religiosos para assessorar os poderes públicos e as organizações socioeconômicas" (Ata do núcleo de Ciências das Religiões de 10/07/1969). Apesar da proposta do curso ser de um estudo "sistemático" e "aconfessional" do fenômeno religioso, inevitavelmente se assume uma reflexão teológica, entretanto, “mais arejada”, ou 
seja, visava "tratar de temas da tradição cristã sem assumir uma postura meramente apologética” (PIEPER, 2018). Motivo pelo qual parte do clero local se sentia ameaçado. Porém, cabe ressaltar que tal postura não traduz a totalidade da perspectiva teológica da comunidade eclesial, uma vez que a proposta do curso de Ciências da Religião era encampada por religiosos e clérigos seculares, que mais tarde, inclusive, viriam a se tornar arcebispos5 (TEIXEIRA, 2012, p. 538-542; PIEPER, 2018).

Também a criação do Programa de Pós-Graduação em Ciências da Religião da PUC SP (nome original), em 1978, que somente em 2015 começa a ter uma orientação oficial alinhada a Religionwissenschaft ${ }^{6}$, surgiu com uma grande colaboração entre Teologia e Ciências da Religião. Edênio Valle, renomado psicólogo da religião e primeiro coordenador do Programa de Ciências da Religião da PUC SP, menciona ao menos dois distintos modelos epistemológicos da teologia na ocasião: as que se limitaram a uma autorreferência eclesial (as que ficaram na "sacristia"), e as "teologias inteligentes", que "aceitam o desafio do pensamento", como a teologia latino-americana, que tinha interlocutores da Ciências Sociais, História e Política (MARQUES; ROCHA, 2007, p. 192-203). Queiroz, também da PUC SP, chega a mencionar o fato de que o Programa de Ciências da Religião teve como "principais mentores", além de seus colegas, como Valle, o "pessoal do Departamento de Teologia”, para pensar cientificamente o fenômeno religioso, e sem este grupo "o programa de Ciências da Religião da PUC-SP não existiria”. Ademais, ambas as disciplinas compartilhavam de um "referencial teórico dialético" para procurar compreender "o que seria uma religião no contexto latino-americano", por meio de

\footnotetext{
${ }^{5}$ Dom Eduardo Benes de Sales Rodrigues (Arcebispo Emérito de Sorocaba, 2005-2016) e Dom Walmor Oliveira de Azevedo (atual Arcebispo de Belo Horizonte) foram professores do Departamento de Ciências da Religião da UFJF, cf. PIEPER, 2018)

${ }^{6}$ A primeira edição da REVER que faz referência ao Programa como Ciência da Religião é do volume 15, n. 1, de 2015. As edições anteriores ainda faziam menção ao Programa de Estudos Pós-graduados em Ciências da Religião. Cf. REVER - Revista de Estudos da Religião. PEPGCR PUC SP. Disponível em $<$ http://revistas.pucsp.br/rever/issue/view/1339 >. Acesso em 23 dez. 2018. Atualmente o se intitula como Programa de Estudos Pós-Graduados em Ciência da Religião da PUC SP e tem duas linhas de pesquisas intituladas Estudo Sistemático da Religião e Estudos Empíricos da Religião, ambas iniciadas em 04/01/2016. Até então o debate epistemológico se concentrava majoritariamente na linha intitulada Fundamentos das Ciências da Religião que funcionou de 01/01/2012 até 31/12/2015. Cf. BRASIL. Ministério da Educação. CAPES - Coordenação de Aperfeiçoamento de Pessoal de Nível Superior. Plataforma Sucupira. Brasília: Fundação $\quad$ CAPES, $2014 . \quad$ Disponível $\quad$ em $<$ https://sucupira.capes.gov.br/sucupira/public/consultas/coleta/programa/viewPrograma.jsf?popup=true\&cd_pro grama $=33005010009 \mathrm{P} 0>$. Acesso em 23 dez. 2018 .
} 
uma "análise dialética da religião" e uma "análise dialética da sociedade”. Afirma Queiroz:

Não havia, portanto, o pensamento de que deveríamos nos separar da Teologia porque ela segue por um viés e nós vamos por outro, não havia essa discussão. O que existia, sim, era um bom senso de enfoque [...] então, a nossa perspectiva política, além de científica, era de não-separação da Teologia, mas de soma para que com essa área pudéssemos implementar uma pós-graduação em Teologia e Ciências da Religião (MARQUES; ROCHA, 2007, p. 204-206).

Ademais, alguns programas de Pós-Graduação haviam elaborado propostas de Teologia e, por critérios alheios aos próprios docentes idealizadores, foram instituídos como Programas de Pós-Graduação em Ciências da Religião, de acordo com o parecer dos órgãos normativos na época. É o caso, por exemplo, da UMESP, em 1979, e do Mackenzie, em 2002 (MARQUES; ROCHA, 2007, p. 208-214).

Tais fatos evidenciam uma disposição histórica para uma clara tendência de configuração de um caráter sui generis da relação entre Teologia e Ciências da Religião no caso brasileiro. Entretanto, tal relação não se limita aos fatos de cooperação e de relação amistosa, em não poucos momentos e entre pesquisadores, mas também inaugura um novo debate epistemológico que já caminha para quase meio século, desde a fundação do Departamento de Ciências da Religião da UFJF, em 1969, e que repercute diretamente na autonomia e criação da Área de Ciências da Religião e Teologia pela CAPES, em 2016, como sendo "mais voltada para uma fundamentação interdisciplinar” (SENRA, 2012a, p. 252, nota 3).

Julga-se aqui que a apropriação desse debate é de fundamental importância, tanto para cientistas da religião como para a teologia, pois delineia um quadro cultural e um modelo epistemológico que interfere diretamente e de modo positivo em estabelecimentos de áreas de concentração, linhas de pesquisa, projetos de pesquisa e formação de trabalhos em rede entre pesquisadores dessas duas áreas de conhecimento. O que se pretende adiante é trazer uma síntese deste debate.

\section{O DEBATE EPISTEMOLÓGICO NA ÁREA DE CIÊNCIAS DA RELIGIÃo E TEOLOGIA NO BRASIL}

A tarefa epistemológica de uma área de conhecimento é algo que nunca se esgota, pois sempre é chamada a acompanhar os novos desafios da produção de 
conhecimento, que não se limitam tão somente em seus elementos teoréticos (teorias, métodos, distintas ênfases e perspectivas dos sujeitos epistêmicos), mas também pela influência social, cultural e política do contexto da produção de conhecimento. Há com isso, a necessidade de uma calibragem, um ajuste necessário entre os modelos epistemológicos empregados na pragmática de investigação e na natureza da realidade analisada (DUTRA, 2013, p. 303-329), entendida em suas "causas remotas" [emergência das Ciências da Religião no contexto europeu] e "causas próximas de um acontecimento" [a consolidação de uma relação entre duas disciplinas que alcança sua institucionalização como Área de Conhecimento autônoma, chamada Ciências da Religião e Teologia].

Mais do que concluir a questão epistemológica, o que não é possível, se impõe, então, a tarefa de consolidar uma cultura epistemológica (PONDÉ, 2001, p. 11- 66), construindo assim "seu campo epistemológico próprio, salvaguardando as diferenças, as especificidades e as convergências quanto ao nome binário" (CAPES, Documento de Área - Filosofia, 2013, p. 37) dessas duas áreas de conhecimento, que se constituem como Área de Avaliação comum de Ciências da Religião e Teologia no Brasil. A importância de uma cultura epistemológica consolidada é exatamente a sua capacidade de interagir com os fatores culturais, sociais e políticos, não raro externos ao debate acadêmico, mas que provocam interferências normativas. Vale mencionar o momento histórico nacional e a relação entre o cenário religioso e o cenário político que interferem na comunidade acadêmica.

A necessidade de tematizar o debate se dá como exercício de consciência das características históricas e teóricas que se configuraram no desenrolar do debate acadêmico. Isto posto, vale dizer que desde a manifestação de um anseio de institucionalização de uma Área autônoma de Ciências da Religião e Teologia, reconhecida pela CAPES, por parte da comunidade acadêmica brasileira de cientistas da religião e teólogo(a)s, se reconhece nessa interação das áreas sua riqueza e sua vocação a um debate contemporâneo, sendo essa interação seu ponto distintivo:

As Ciências da Religião (ou suas variantes) e a Teologia têm nesse sentido vocação interdisciplinar e a reflexão epistemológica contemporânea mostra como as fronteiras tradicionais entre as diversas áreas vão sendo superadas, evidenciando também que muitas questões novas só podem ser tratadas através da integração entre diferentes saberes (CAPES, Documento de Área - Filosofia, 2013, p. 37-38). 
Novamente, em 2016, com a publicação do Documento de Área, por ocasião da autonomia conquistada, se destaca um "claro perfil interdisciplinar" (CAPES, 2017, p. 8-11). Tal afirmação se respalda no histórico de interação positiva com correntes teológicas e eclesiais da Teologia da Libertação, no caso da tradição católica, e da Missão Integral, no caso da tradição protestante, um caminho distinto do debate europeu desde o século XVIII. Houve uma grande interação multidisciplinar, com grande interesse da teologia latino-americana em incorporar outras ciências para compreender o fenômeno religioso, assim como a religião passa a ser pensada em seu papel social, pelas ciências sociais, e seu papel nos processos de subjetivação e cooperação terapêutica, pela psicologia da religião, questões que são de interesse de teólogos e teólogas, seja de pesquisa, seja de incorporação nos currículos de teologia. Havia uma mudança de mentalidade eclesial que ia assimilando a possibilidade de uma abordagem multidisciplinar que as Ciências da Religião ofereciam, e a teologia apoiava.

Marcelo Camurça entende que as divisões entre Teologia e Ciências da Religião parecem ser muito mais o resultado das clivagens produzidas pelo Iluminismo, que dividiu os conhecimentos entre os "saberes da história, cultura e sociedade" (Ciências da Religião), por um lado, e os "saberes de transcendência" (Teologia e Filosofia da Religião), por outro. Contudo, face à complexidade contemporânea do fenômeno religioso, marcado pela globalização, fragmentação, desregulação das instituições sociais e religiosas, hibridismos de territórios e identidades, diversidade de atores, temas (gênero, sexualidade, ecologia, informática, mídia) que configuram o fenômeno religioso em transição de suas concepções tradicionais, o antropólogo da religião propõe uma perspectiva de articulação entre as distintas perspectivas e métodos, a fim de promover a via da colaboração. De modo a sair de uma postura de tensões estanques para uma "tensão com complementação", ajudando assim a Teologia a uma "redefinição da tarefa" e dos "paradigmas", procurando recuperar "as mediações socioculturais e a historicidade de seus conceitos de revelação" para além do discurso de "legitimidade confessional" (modelo epistemológico especial de fé), para se debruçar, junto com as Ciências da Religião, sobre a crise da modernidade e as questões de desinstitucionalização e recomposições religiosas (CAMURÇA, 2011, p. 12-21). 
Também Fabiano Campos propõe essa perspectiva de indissolubilidade, desde a proposta de Paul Ricoeur, entre abordagens mais explicativas (empíricas) e as mais interpretativas (hermenêuticas), como modo de conexão necessárias entre as diversas disciplinas que se dedicam aos estudos de religião (2018, p. 38-41; 68).

Eduardo Gross propõe, ainda, a distinção entre "teologia" e "teologia cristã", enquanto identificação de procedimentos intelectuais distintos das questões de confissão de fé (GROSS, 2001, p. 323-346). Apesar de alguma resistência dessa perspectiva, essa situação não é estranha nem mesmo para a Teologia Medieval, organizada entre as teologias produzidas em Mosteiro, com o modelo da lectio, acentuadamente bíblicas, e as teologias produzidas na Universidade, que dialogavam com a filosofia aristotélica, transformando a lectio em quaestio.

Se as teologias da libertação e as teologias das religiões permitiram formas de interação críticas e complementares com as Ciências da Religião, atualmente, uma grande tendência é o que se chama de Teologia Pública e seu exercício de tradução de conteúdos religiosos para uma razão pública, em busca de promover interculturalidade, ou seja, uma proposta de pensar desde perspectivas diferentes, em problemas comuns, a fim de encontrar soluções cooperativas para a construção do bem comum e de uma cultura de tolerância e respeito, em perspectiva contra hegemônica (SANTOS, 2013, p. 30; 142; SINNER, 2011, p. 264-276; 2007, p. 338363; ZEFERINO, 2018, p. 18-47). Também o campo de teopoética estabelece uma interface entre as duas áreas de conhecimento e as subáreas de Teologia Fundamental-Sistemática e Ciências da Linguagem Religiosa, como indica a pesquisa de Antonio Cantarela, atualmente com 129 pesquisadores entre cientistas da religião, teólogos(as), críticos(as) literários, filósofos(as), filólogos(as), entre outros, e com 1175 títulos publicados entre artigos, livros, teses e dissertações (CANTARELA, 2018, p. 193-221).

Desta condição, uma das importantes questões para os estudos de religião é pensar a religião como um fenômeno que se configura como um complexo sistema de crença, em que o(a) cientista da religião ajuda a mapear sua dinâmica desde uma perspectiva interdisciplinar e, deste modo, ajuda o teólogo(a) em seu exercício de pensar formas de oferecer uma racionalidade crítica no interior desse sistema de crença, e traduzi-la para uma razão pública, na medida em que incorpora uma agenda social em sua sensibilidade religiosa, criando uma interface entre a teologia 
confessional e a teologia pública. Assim, a Área de Ciências da Religião e Teologia pode realizar uma hermenêutica diatópica do mesmo fenômeno religioso, ou seja, um exercício de interpretação através de seus lugares de fala [dia-tópos], mas com uma disposição interdisciplinar, em que cada um ajuda a identificar melhor os respectivos pontos cegos de percepção, que inevitavelmente existem em cada lugar de observação. Ademais, as epistemologias do sul vão se configurando como um campo que tende a se estabelecer em uma via de perspectiva compartilhada entre as duas áreas de conhecimento, Ciências da Religião e Teologia (BAPTISTA, 2018, p.94-114; 2016, p. 491-517).

Entretanto, apesar desse histórico de interação interdisciplinar, não é um consenso no Brasil o modo de pensar a relação entre Ciências da Religião e Teologia, especialmente entre autores que mantêm a posição alemã [Religionswissenschaft] de uma afirmação da disciplina em negação à Teologia (USARSKI, 2006, p. 15; 2001, p. 67-103; GRESCHAT,2006, p. 155; FILORAMO; PRANDI, 1999, p. 22-23). Tal postura, apesar de ser minoritária, também é importante para o debate, pois essa tensão dinamiza a tarefa do diálogo a aprofundar a pragmática da investigação e a calibragem interdisciplinar. A crítica da Escola Alemã da Ciência da Religião, além de ajudar a epistemologia própria a não se transformar em formas de "criptoteologia", colabora para a tarefa sempre necessária de policiar a Teologia de ceder à tentação de estabelecer sua fundamentação "meramente baseada na revelação divina", o que blinda a religião de ser entendida também como produto humano e histórico, incorrendo em pretensas justificações como modelos de "organização hierárquica", o "poder de sacerdotes sobre leigos" ou "legitimação de regimes políticos" (USARSKI, 2006, p. 67; 40; 21-22).

Vale dizer que para uma grande maioria de cientistas da religião e teólogos, essa inegável tensão promove uma relação salutar no caso brasileiro (ARAGÃO, 2015, p. 319-337; 2011, p. 95-142; TEIXEIRA, 2013, p. 175-183; SOARES, 2013, p. 649-661; BRIGHENTI, 2013, p. 663-676; LIBÂNIO, 2011, p. 43-64; WACHHOLZ, 2011, P. 199217). Mesmo entre docentes dos Programas de Pós-Graduação que se intitulam Ciência da Religião, seguindo o modelo alemão [Religionwissenschaft], como é o caso da UFJF e da PUC SP, há diversos autores dessas respectivas instituições que tem uma perspectiva positiva em relação ao papel da Teologia nas Ciências da Religião, indicando que a separação entre as duas áreas de conhecimento não tem 
grande apoio (TEIXEIRA, 2001, p. 297-322; GROSS, 2001, p. 323-346; CAMURÇA, 2008, p. 41-67; 2011, p. 12-28; MARQUES; ROCHA, 2007, p. 192-203; p. 204-206; SOARES, 2007, p. 281-306; 2011; 2013, p. 640-661; CRUZ, 2011; 2013, p. 115-127; PASSOS, 2010, p. 69-104).

À vista disso, mesmo não sendo um consenso o modo de ver a relação entre Ciências da Religião e Teologia, há uma inegável tendência mais evidente e consolidada com a proposta de uma perspectiva interdisciplinar nos estudos de religião, presente desde o surgimento das Ciências da Religião no Brasil, com inevitáveis momentos de tensão, que não raro foram oriundos de influências externas ao debate acadêmico, mas que foi crescendo para ser cada vez mais uma via cooperativa de perspectiva intercultural (SOARES, 2013, p. 650) e compartilhada (GISEL, 2011, p. 165-192) do campo de estudos, na medida em que vai desenvolvendo pesquisas interdisciplinares e transdisciplinares.

Uma tarefa que se impõe é o reconhecimento e o mapeamento de modelos epistemológicos da teologia que, não raro, são vistos como sendo únicos, não somente por cientistas da religião, mas também por teólogos e teólogas.

\subsection{A tarefa de uma pragmática de modelos epistemológicos}

Uma das questões importantes da epistemologia contemporânea é a pragmática de modelos, como tarefa de superação de uma visão epistemológica essencialista e ideal, para elaborar modelos contextuais e institucionais a respeito de um mesmo objeto cultural, reconhecendo assim o valor da complementação das perspectivas e a condição de complexidade de um fenômeno analisado. Tal pragmática de modelos ajuda a perceber a inter-relação possível entre sistemas, ao identificar insuficiências e valorizar peculiaridades entre eles, promovendo uma interculturalidade (DUTRA, 2013, p. 331-335). Isto posto, pode-se aplicar à teologia e às ciências da religião, enquanto sistemas que compõe um sistema maior, as ciências humanas, e que compartilham perspectivas e saberes acumulados em torno de um mesmo objeto cultural, o fenômeno e o fato religioso.

Um autor que tem se dedicado ao debate epistemológico da área é Flávio Augusto Senra Ribeiro, docente do Programa de Pós-Graduação em Ciências da Religião da PUC Minas e atual coordenador da Área de Ciências da Religião e 
Teologia na CAPES. Senra inicia uma classificação de modelos epistemológicos desde a perspectiva foucaultiana, de uma arqueologia do saber, a fim de entender o discurso teológico, como um discurso “de” e "sobre Deus”, que participa do mesmo contexto de outros discursos e práticas, de acordo com "as condições do saber em diferentes épocas", identificando assim "rupturas epistemológicas". Na epistémê renascentista, da Antiguidade até a época do Renascimento (século XVI), Deus "fala" através do mundo, de modo que é necessário "saber lê-lo nas coisas do mundo", através do qual se manifesta, na semelhança entre palavras e coisas, pois Deus teria colocado no mundo suas marcas, a fim de serem lidas e reconhecidas, e assim ser compreendido através de Sua criação; Na epistémê clássica, ou da Idade Clássica, como classificada por Foucault (séculos XVII e XVIII), há a tarefa de explicar a "ideia de Deus “ pela "razão”, dentro de uma “episteme da representação”, que possibilitaria representar uma ordenação racional das coisas, colocando, assim, "para a reflexão teológica o problema de conceituar racionalmente Deus e demarcar os espaços de sua manifestação”. Assim, diz o autor, “o discurso de Deus nas coisas e a possibilidade de acesso a ele, através das coisas do mundo, são substituídos pela ideia e pela representação, deixando Deus de habitar o "mundo das coisas" para "habitar o mundo dos conceitos puros”. Na epistémê moderna (século XIX), com a morte de Deus, a possibilidade de uma reflexão metafísica é substituída por uma analítica da finitude no pensamento moderno, de modo a se superar a pretensão de uma "vontade de se estabelecer uma verdade absoluta”, pois o "conhecimento é limitado" e "já não se pode conhecer tudo: Deus, alma e a totalidade do mundo" (SENRA; PINTO, 2010, p. 48-57).

Impõe-se como desafio a questão da morte de Deus, que denuncia a metafísica entendida como ilusão pela filosofia da vida, como alienação pela filosofia do trabalho e como episódio cultural pela filosofia da linguagem. Entretanto, o próprio Foucault aponta um caminho que não é estranho às tradições religiosas, entendidas não sem suas pretensões de hegemonia, sustentadas por estruturas metafísicas, mas em sua capacidade sapiencial, de um pensar produtor de práticas significativas e pertinentes aos desafios da sociedade. Nas palavras do próprio Foucault: 
A atividade do espírito [...] não mais consistirá, pois, em aproximar as coisas entre si, em partir em busca de tudo o que nelas possa revelar como que um parentesco, uma atração ou uma natureza secretamente partilhada, mas ao contrário, em discernir [...]. Nesse sentido, o discernimento impõe à comparação a busca primeira e fundamental da diferença: obter pela intuição uma representação distinta das coisas e apreender claramente a passagem necessária de um elemento da série àquele que se lhe sucede imediatamente [...] conhecer é discernir (FOUCAULT, 1966, p. 68).

Senra recoloca assim o desafio da morte de Deus como ponto de partida do debate epistemológico e evoca o saber de uma teologia negativa e suas formas de relação entre política, cultura e teologia, e portanto, desconstruindo os excessos e abusos (SENRA; PINTO, 2010, p. 56; BERNAUER, CARRETTE, 2004, p. 1-9; 76138). Contudo, apesar da apresentação histórica das rupturas epistemológicas na perspectiva foucaultiana, o autor faz a ressalva de que os "distintos momentos epistemológicos" ainda "acabam por conviver, sob múltiplos aspectos, nos dias atuais”, o que pode indicar uma deficiência no debate sobre epistemologia teológica, o que resultaria na "emergência no cenário recente de discursos de natureza fundamentalista em certos segmentos religiosos”. Esse anacronismo epistemológico da teologia já fora denunciado pela crítica nietzschiana, que aponta "teólogos mal instruídos que querem brincar de filósofos", na tentativa de "imposição do ideal sobre a verdade do mundo", simplificando a complexidade do real (SENRA, 2012b, p. 126132).

Além da distinção de momentos epistemológicos, bem como um possível anacronismo que se situa na tensão entre método dedutivo e indutivo, e da necessidade de desvelar questões ideológicas sob a roupagem de teologia, há que se realizar algumas importantes distinções em relação ao risco de reducionismo anacrônico da perspectiva da Religionwissenschaft, que se deu inicialmente com os teólogos no século XIX na Europa, mais particularmente a distinção entre 1) teologia investigativa e teologias normativas. As primeiras pautadas pelo exercício crítico da pesquisa, sobretudo a hermenêutica em diálogo com outras áreas de saber, e a segundo entendida como teologia oficial de uma determinada tradição de fé (GENOVESI, 2008, p. 67-92); 2) as correntes distintas da teologia investigativa no século XIX e o modo como cada uma interpretou e se apropriou do debate epistemológico de seu tempo; 3) personagens históricas que influenciam as teologias normativas, sejam seus líderes mundiais, sejam as representações locais que o 
recebem, nem sempre sem tensões também. Com efeito, um futuro historiador da religião, por exemplo, que se dedique à história recente do catolicismo na mudança de Milênio, independentemente de ter alguma relação com a fé católica ou não, inevitavelmente terá que identificar as diferenças teológicas dos pontífices da segunda metade do século XX e da primeira metade do século XXI, como a tarefa de analisar as diferentes perspectivas, e por vezes diferenças radicais, de personagens históricos como Pio XII, João XXIII, Paulo VI, João Paulo II, Bento XVI e Francisco. Furtar-se dessa tarefa, seja para teólogo(a)s seja para cientistas da religião, é incorrer no risco de ficar no senso comum.

Ademais, face ao desenrolar do desafio epistemológico da complexidade que, progressivamente, exige uma consciência analítica multifatorial, o debate epistemológico da Área de Ciências da Religião e Teologia assume características de uma "tendência interdisciplinar" nos Estudos de Religião no Brasil, acompanhando, assim, a mudança de cultura acadêmica de pensar a interdisciplinaridade como "nova etapa do conhecimento" e nova metodologia do "trabalho científico contemporâneo". Nesse sentido, identificar esse traço interdisciplinar indica a posição da área diante do "movimento interdisciplinar em três momentos (SENRA, 2012a, p. 261): 1) conceituação básica (anos 70): com uma preocupação mais terminológica; 2) construção de diretrizes sociológico-metodológicas (anos 80): promovendo uma revisão das contradições epistemológicas; e 3) teorização de uma epistemologia interdisciplinar (anos 90), integrando um projeto antropológico e, portanto, entendida a necessidade de mudança de mentalidade. Tal processo se dá em distintos níveis de interação das disciplinas:

1) Multidisciplinaridade - nível inferior de integração, busca cooperação entre disciplinas na solução de um problema, sem que tal integração contribua para modificá-las ou enriquecê-las, não implica a impossibilidade de alcançar níveis superiores;

2) Interdisciplinaridade - segundo nível de integração, no qual a integração promove intercâmbios reais, ocorrem enriquecimentos múltiplos;

3) Transdisciplinaridade - construção de um sistema total, sem fronteiras sólidas entre as disciplinas, ou seja, "uma teoria geral de sistemas ou estruturas, que inclua estruturas operacionais, estruturas de regulamentação e sistemas probabilísticos, e que una estas diversas possibilidades por meio de transformações reguladas e definidas". (PIAGET apud SENRA, 2012a, p. 262-263). 
Se impõe, assim, uma tarefa do labor teológico de modo interdisciplinar, especialmente com a Ciências da Religião, para melhor realizar uma autocrítica, bem como enriquecer o campo de Estudos de Religião desde uma perspectiva compartilhada de um mesmo campo de pesquisa, bem como de postura dos sujeitos epistêmicos:

o inimigo a ser combatido é aquele da superstição paralisante e o do domínio religioso que escraviza pelo dogmatismo, pelo transcendentalismo e pela negação das condições humanas e sociais para a construção do mundo ético e justo no aquém do transcendental e extra-mundano mundo divino (SENRA; PINTO, 2011, p. 49; 126-132).

\section{CONSIDERAÇÕES FINAIS}

A questão epistemológica da comunidade teológica brasileira tem longa data, coincidindo com a idade do país, e sofre influências pelo contexto social, político e cultural. Apesar do acentuado modelo da segunda escolástica, há desde os primórdios ao menos uma aproximação de práticas etnográficas, que se aproximavam da pesquisa antropológica para uma elaboração teológica, por parte dos jesuítas. Contudo, o contexto da sua expulsão, no Regime da Coroa Unificada, bem como da desconfiança da formação teológicas das ordens religiosas, por Marques de Pombal, inaugura uma acentuada influência jansenista na cultura teológica brasileira, marcada pelo rigorismo moral, pessimismo antropológico, uma certa epistemologia especial da fé, e uma ênfase apologética, que se retroalimenta, no caso católico, com a criação dos seminários de teologia protestante, desde a segunda metade do século XIX.

Diferente da comunidade teológica europeia, que já na primeira metade do século XX revela um movimento de renovação teológica, na comunidade teológica brasileira, esse movimento só aconteceria após o Concílio Vaticano II. Um dos elementos sintomáticos dessa diferença é, por exemplo, a figura de Tomás de Aquino, que na Europa era visto como modelo de diálogo da Escola Francesa e da Escola Alemã, ao passo que no Brasil, seguindo a influência da Escola Romana, foi visto como modelo de combate às heresias.

Concomitante ao movimento de renovação teológica católica, e também protestante, na segunda metade do século XX, por parte da Teologia da Libertação e 
da Missão Integral, ambas adotando o método indutivo como teologia contextual, surgem também no Brasil os cursos de Ciências da Religião, que distintos do modelo alemão da Religionswissenschaft, recebem apoio e incentivo da comunidade teológica, configurando-se, assim, como um caso sui generis e dando início a uma cultura epistemológica de caráter interdisciplinar entre teólogo(a)s e cientistas da religião. Tal debate chega a quase 50 anos, tendo por início a criação do departamento de Ciências da Religião na Universidade Federal de Juiz de Fora, em 1969. Mesmo não sendo um consenso geral, a tensão crítica de perspectivas tem propiciado maior interação da comunidade de cientistas da religião e de teólogos(as) brasileiros(as), confirmando cada vez mais tal tendência, chegando a formar um grupo de trabalho na Sociedade de Teologia e Ciências da Religião (SOTER) e na Associação Nacional de Pós-Graduação e Pesquisa em Teologia e Ciências da Religião, promovendo inclusive alguns encontros entre pesquisadores das duas áreas de conhecimento 7 .

Deste modo, uma das tarefas que vai se apresentando dessa interação é a necessidade de mapear os distintos modelos epistemológicos da teologia, a fim de melhor identificar as possíveis cooperações de trabalho investigativo e de perspectivas compartilhadas entre os respectivos modelos epistemológicos das Ciências da Religião e Teologia, e os diversos sujeitos epistêmicos de ambas, a fim de avançar para um trabalho em rede e multidisciplinar, que melhor atenda às características multifatoriais dos fenômenos e fatos religiosos contemporâneos. O mapeamento de modelos epistemológicos permite também clarear casos de incompatibilidade entre teologia (apologético, proselitista...) e ciências da religião, sem cair na tentação de uma perspectiva reducionista e generalista de cada área de conhecimento. Com isso, apresenta-se a necessidade de fortalecer e avançar para uma cultura epistemológica que fomente o exercício autocrítico da teologia, como oferta de racionalidade a um sistema de crença capaz de enfrentar o cenário de contradições do cenário religioso, procurando compreender tais causas multifatoriais dos respectivos fenômenos religiosos, não somente como uma questão eclesial, mas

\footnotetext{
${ }^{7}$ 1) V Colóquio do Grupo de Pesquisa Religião e Cultura: A epistemologia das Ciências da Religião: pressupostos, questões e desafios, PUC Minas, 17 a 19 de outubro de 2017; 2) VI Colóquio do Grupo de Pesquisa Religião e Cultura: Teoria da Religião nas Ciências da Religião, PUC Minas, 08 a 10 de agosto de 2018; 3) HUMANITAS - I Congresso Internacional do Programa de Pós-Graduação em Teologia da PUC PR: Teologia em diálogo com as Ciências Humanas: Novos desafios epistemológicos, PUC PR, 29 de outubro a 01 de novembro de 2018.
} 
vendo a religião em seu impacto cultural, social, econômico e político e seus respectivos processos de subjetivação, ou seja, uma cultura epistemológica que dialogue com uma razão pública.

\section{REFERÊNCIAS}

ANJOS, J. J. T. O Catecismo de Montpellier e a educação da criança no Brasil Imperial. Cadernos de Pesquisa, v.46 n.162 (2016), p.1028-1048.

ARAGÃO, G. Encruzilhada dos Estudos de Religião No Brasil. Revista de Teologia e Ciências da Religião, UNICAP, V. 5, n. 1, 2015, p. 319-337.

ARAGÃO, G. Sobre epistemologias e diálogos: Fenomenologia, diálogo inter-religioso e hermenêutica. In: CRUZ, E. R.; DE MORI, G. Teologia e Ciências da Religião. São Paulo; Belo Horizonte: ANPTECRE/Editora PUC Minas/Editora Paulinas, 2011, p. 95-142.

AZEVEDO, João Lúcio (1918). História de Antônio Vieira. Tomo I. Alameda Casa Editorial: São Paulo, 2008.

BAPTISTA, P.A. N. Desafios das Epistemologias Decoloniais e do Paradigma Ecológico para s Estudos de Religião. Interações, Belo Horizonte, v. 13. n. 23 (2018), p. 94-114.

BAPTISTA, P.A. N. Pensamento decolonial, teologias pós-coloniais e Teologia da Libertação. Perspectiva Teológica, Belo Horizonte, v. 48, n. 3, (2016) p. 491-517.

BEA, A. La Costituzione Apostolica "Deus Scientiarum Dominus": Origine e Spirito. In: Gregorianum, v. 22, n. 4 (1941), p. 445-466.

BERnAUER, J; CARRETTE, J. Michel Foucault and Theology: The Politics of Religion Experience. Routledge: London/New York, 2004.

BESEN, José Artulino. Seminário de Azambuja: 1927-2002. Florianópolis: Colaboradores - AESA, 2002.

BOURDIEU, P. Contrafogos: táticas para enfrentar a invasão neoliberal. Rio de Janeiro: Jorge Zahar, 1998.

BRIGHENTI, A. Ciência da Religião aplicada à ação pastoral in PASSOS, J. D; USARSKI, F. Compêndio de Ciência da Religião. São Paulo: Paulinas/Paulus, 2013, p. 663-676. 
CAMPOS, F.V. Explicar e compreender: a querela em torno do procedimento epistemológico próprio da Ciência da Religião. Interações, v. 13. n. 23 (2018), p.3872.

CAMURÇA, M. Ciências Sociais e Ciências da Religião: polêmica e interlocuções. São Paulo: Paulinas, 2008.

CAMURÇA, M. Les Sciences Religieuses: um olhar a partir do Brasil para o campo de estudo das Ciências da Religião na França. Estudos de Religião, v. 25, n. 41 (2011), p. 12-28.

CANTARELA, A. A produção acadêmica em Teopoética no Brasil: pesquisadores e modelos de leitura. Teoliterária, v. 8, n. 15 (2018), p. 193-221.

CAPES. Ciências da Religião e Teologia. Relatório de Avaliação, 2017. Disponível em: <http://capes.gov.br/component/content/article/74-dav/caa2/4643teologia>. Acesso: 25 mai. 2018.

CAPES. Documento de Área: Filosofia, 2013. Disponível em: <http://www.capes.gov.br/component/content/article/44-avaliacao/4644-filosofia> Acesso: 25 mai 2018.

CHENU, M-D. La Teologia nel XII Secolo. Milano: Jaca Book, 1983.

CRUZ, E. R. Estatuto Epistemológico da Ciência da Religião. In: PASSOS, J. D; USARSKI, F. Compêndio de Ciência da Religião. São Paulo: Paulinas/Paulus, 2013, p. 37-49.

CRUZ, E.; DE MORI, G.(orgs.). Teologia e Ciências da Religião: A caminho da maioridade acadêmica no Brasil. São Paulo: Belo Horizonte: ANPTECRE/Editora PUC Minas/Editora Paulinas, 2011.

DUTRA, L. H. A. Pragmática de Modelos: natureza, estrutura e uso de modelos científicos. São Paulo: Edições Loyola, 2013.

FILORAMO, G. \& PRANDI, C. "Para um Estudo Científico da Religião"; "Posfácio à III Edição Italiana”. As Ciências das Religiões. São Paulo: Paulus, 1999, p. 05-25; 285-290.

FOUCAUlT, Ml. (1966). As Palavras e as Coisas: Uma arqueologia das ciências humanas. Tradução: Salma Tannus Muchail. São Paulo: Martins Fontes, 2000.

GEDEON, A. Protestantismo Tupiniquim: Hipóteses sobre a não contribuição evangélica à cultura brasileira. São Paulo: Arte Editorial, 2005.

GENOVESI, V. J. Em busca do amor: moralidade católica e sexualidade humana. trad.: Barbara Theoto Lambert. São Paulo: Edições Loyola, 2008. 
GISEL, P. Teologia e Ciências das Religiões: por uma oposição em perspectiva. Perspectiva Teológica, v. 43, n. 120 (20110, p. 165-192.

GRESCHAT, H-J. O que é Ciência da Religião. Col. Repensando a Religião. São Paulo: Paulinas, 2006.

GROETHUYSEN, B. Les Origines d'esprit bourgeois en France. Paris: Edité par NRF Gallimard, 1927.

GROSS, E. Considerações sobre a Teologia entre os Estudos de Religião. In: TEIXEIRA, F. A(s) Ciência(s) da religião no Brasil: afirmação de uma área acadêmica. São Paulo: Paulinas, 2001, p. 323-346.

HUGO DE SÃO VITOR. Didaschalion ou a Arte de Ler. Petrópolis: Editora Vozes, 2001.

LIBÂNIO, J.B. A religião no início do Milênio. In: CRUZ, E; DE MORI, G. Teologia e Ciências da Religião: A caminho da maioridade acadêmica no Brasil. São Paulo: Belo Horizonte: ANPTECRE/Editora PUC Minas/Editora Paulinas, 2011, p. 43-64.

MINISTÉRIO DA EDUCAÇÃO. Diretrizes Curriculares Nacionais para o curso de graduação em Teologia (versão prévia a homologação). CNE/CES $60 / 2014$.

MELO, A. J. Jansenismo no Brasil: traços históricos de uma moral rigorista. Aparecida: Editora Santuário, 2014.

MENDONÇA, A. G; VELASQUES FILHO, P. Introdução ao Protestantismo no Brasil. 2 ${ }^{\mathrm{a}}$. Ed. São Paulo: Edições Loyola, 2002.

PASCAL, B. Oeuvres Completes. L. Hachette et Cie: Paris, 1858 [Kindle Edition]. PIEPER, F. Aspectos históricos e epistemológicos da Ciência da Religião no Brasil. Um estudo de caso. op.mimeo. 2018

PONDÉ, L.F. Em busca de uma Cultura Epistemológica. In: TEIXEIRA, F. (org.). A(s) Ciência(s) da religião no Brasil. São Paulo: Paulinas, 2001, p. 11- 66.

SANGENIS, L. F. C. Gênese do Pensamento Único em Educação: Franciscanismo e Jesuitismo na Educação Brasileira. Petrópolis: Editora Vozes, 2006.

SANTOS, B. S. Se Deus fosse um ativista dos direitos humanos. São Paulo: Cortez, 2013.

SCANNONE, J. L. La Teología de la Liberación: Caracterización, corrientes, etapas. Stromata, ano 38, n. 1/2, 1982: p. 3-40. 
SENRA, F. A verdade como um exército de metáforas: Entre o dogmático e o est ético em religião e literatura. In: Teoliterária: Revista Brasileira de Literaturas e Teologias, v. 2, n. 4 (2012b), p. 123-132.

SENRA, F.; FERREIRA, A. C. Tendência interdisciplinar das Ciências da Religião no Brasil: O debate epistemológico em torno da interdisciplinaridade e o paralelo com a constituição da área no país. In: Numen, v. 15, n. 2, (2012a), p. 249-269.

SENRA, Flavio; PINTO, Helder de S. Silva. Rupturas epistemológicas e o discurso sobre Deus. Uma leitura a partir de Michel Foucault. Horizonte, v. 8, n. 18, (2010), p. 27-64.

SERBIN, K. P. Padres, celibato e conflito social: uma história da Igreja Católica no Brasil.Tradução Laura Teixeira Motta. São Paulo: Companhia das Letras, 2008.

SINNER, R. Teologia pública no Brasil. In: SOARES, A.; PASSOS, J. (Orgs.). Teologia pública: reflexões sobre uma área de conhecimento e sua cidadania acadêmica. São Paulo: Paulinas, 2011, p. 264-276.

SOARES, A. Ciência da Religião aplicada à Teologia. In: PASSOS, J. D; USARSKI, F. Compêndio de Ciência da Religião. São Paulo: Paulinas/Paulus, 2013, p. 649661.

SOARES, A. M.L. A Teologia em diálogo com a Ciência da Religião. In: USARSKI, F. (org.). O Espectro disciplinar das Ciência da Religião. São Paulo: Paulinas, 2007, p. 281-306.

SOARES, A. M. L. Ciência da Religião aplicada à Teologia. In: PASSOS, J. D; USARSKI, F. Compêndio de Ciência da Religião. São Paulo: Paulinas/Paulus, 2013, p. 649-661.

TEIXEIRA, F. A(s) Ciência(s) da religião no Brasil: afirmação de uma área acadêmica. São Paulo, Paulinas, 2001.

TEIXEIRA, F. Ciência da Religião e Teologia. In: PASSOS, J. D; USARSKI, F. Compêndio de Ciência da Religião. São Paulo: Paulinas/Paulus, 2013, p. 175183 .

TEIXEIRA, F. O processo de gênese da (s) ciência (s) da religião na UFJF. Numen: revista de estudos e pesquisa da religião, v. 15, n. 2, (2012), p. 537-550.

TORRES-LONDOÑO, Fernando. As Constituições do Arcebispado da Bahia de 1707 e a presença da escravidão. In: Anais da VI Jornada Setecentista do CEDOPE Centro de Documentação e Pesquisa em História da Universidade Federal do Paraná. Curitiba: Editora UFPR, 2005, p. 275-282.

USARSKI, F. Constituintes da Ciência da Religião. Col. Repensando a Religião. São Paulo: Paulinas, 2006. 
USARSKI, F. Perfil Paradigmático da Ciência da Religião na Alemanha. In: TEIXEIRA, Faustino (org.). A(s) Ciência(s) da religião no Brasil: Afirmação de uma área acadêmica. São Paulo, Paulinas, 2001, p. 67-103.

MARQUES, Â. C. B.; ROCHA, M. Memórias da fase inicial da Ciência da Religião no Brasil - Entrevistas com Edênio Valle, José J. Queiroz e Antonio Gouvêa Mendonça. REVER - Revista de Estudos da Religião, n. 1, (2007), p. 192-214.

VIEIRA, A. (1626). Carta Ânua Ao geral da Companhia de Jesus, 30 de setembro de 1626. In: VIEIRA, A. Cartas do Brasil. João Adolfo Hansen(org). São Paulo: Hedra, 2003.

VILLAS BOAS, A. Misericórdia e Alteridade na Perspectiva Teológica do Papa Francisco. Livre Docência em Ética e Linguagem Teológica (Tese). São Paulo: PEPG Teologia PUC SP, 2017.

ZEFERINO, J. Karl Barth e Teologia Pública: Contribuições ao Discurso Teológico Público na Relação entre Clássicos Teológicos e Res Publica no horizonte da Teologia da Cidadania. Doutorado (Tese). PPGT PUC PR: Curitiba, 2018.

ŽIŽEK, S. Como ler Lacan. Rio de Janeiro: Zahar, 2006.

Recebido em: 19.10 .2018

Aprovado em: 24.12.2018 
Anexo: IES de Teologia no Brasil, 2018

\begin{tabular}{|c|c|c|c|c|c|}
\hline Região & $\mathbf{U F}$ & $\begin{array}{c}\text { Cursos } \\
\text { Presenciais } \\
\end{array}$ & EaD & Total & $\begin{array}{c}\text { Mestrado/Mestrado } \\
\text { Profissional/Doutorado }\end{array}$ \\
\hline \multirow{10}{*}{ Sudeste } & \multirow{5}{*}{ SP } & \multirow{5}{*}{37} & \multirow{5}{*}{26} & \multirow{5}{*}{63} & PUC SP (M/D) \\
\hline & & & & & PUC SP (M/D)* \\
\hline & & & & & UMESP* \\
\hline & & & & & PUC Camp (M)* \\
\hline & & & & & Mackenzie (M)* \\
\hline & RJ & 21 & 23 & 44 & PUC Rio (M/D) \\
\hline & \multirow{4}{*}{ MG } & \multirow{4}{*}{13} & \multirow{4}{*}{21} & \multirow{4}{*}{34} & FAJE (M/D) \\
\hline & & & & & UFJF (M/D)* \\
\hline & & & & & PUC Minas (M/D)* \\
\hline & & & & & $\begin{array}{l}\text { PUC SP (DINTER)* } \\
\end{array}$ \\
\hline & $\mathrm{ES}$ & 2 & 15 & 17 & FUV (MF) * \\
\hline & & 73 & 85 & 158 & \\
\hline \multirow[t]{4}{*}{ Sul } & PR & 16 & 25 & 41 & $\begin{array}{l}\text { PUC PR (M/D) } \\
\text { FABAPAR (MF) }\end{array}$ \\
\hline & $\mathrm{RS}$ & 9 & 17 & 26 & $\begin{array}{l}\text { PUC RS (M/D) } \\
\text { EST (M/MF/D) }\end{array}$ \\
\hline & $\mathrm{SC}$ & 4 & 17 & 21 & \\
\hline & & 29 & 59 & 88 & \\
\hline \multirow{6}{*}{ Centro-Oeste } & $\mathrm{DF}$ & 7 & 14 & 21 & MINTER (FAJE) \\
\hline & \multirow{2}{*}{ GO } & \multirow{2}{*}{7} & \multirow{2}{*}{18} & \multirow{2}{*}{25} & PUC GO (M/D)* \\
\hline & & & & & MINTER (PUC GO)* \\
\hline & MT & 3 & 19 & 22 & \\
\hline & MS & - & 18 & 18 & \\
\hline & & 17 & 69 & 86 & \\
\hline \multirow[t]{11}{*}{ Nordeste } & $\mathrm{CE}$ & 10 & 14 & 24 & \\
\hline & $\mathrm{BA}$ & 9 & 19 & 28 & MINTER (EST) \\
\hline & \multirow{2}{*}{$\mathrm{PE}$} & \multirow{2}{*}{5} & \multirow{2}{*}{18} & \multirow{2}{*}{23} & UNICAP (M) \\
\hline & & & & & UNICAP (M)* \\
\hline & MA & 3 & 16 & 19 & \\
\hline & PI & 3 & 12 & 15 & \\
\hline & $\mathrm{RN}$ & 2 & 11 & 13 & \\
\hline & $\mathrm{PB}$ & 1 & 9 & 10 & $\mathrm{UFB}^{*}$ \\
\hline & $\mathrm{SE}$ & - & 12 & 12 & UFS* \\
\hline & $\mathrm{AL}$ & - & 12 & 12 & \\
\hline & & 33 & 99 & 132 & \\
\hline \multirow[t]{9}{*}{ Norte } & PA & 5 & 15 & 20 & UEPA* \\
\hline & $\mathrm{RO}$ & 2 & 14 & 16 & \\
\hline & $\mathrm{RR}$ & 1 & 9 & 10 & \\
\hline & $\mathrm{AC}$ & 1 & 8 & 9 & MINTER/DINTER (FAJE) \\
\hline & $\mathrm{AM}$ & - & 11 & 11 & DINTER (EST) \\
\hline & TO & - & 11 & 11 & \\
\hline & $\mathrm{AP}$ & - & 8 & 8 & \\
\hline & & 9 & 76 & 85 & \\
\hline & & 161 & 388 & 549 & \\
\hline
\end{tabular}

Fontes: MEC, Cadastro e-MEC de Instituições e Cursos de Edu cação Superior e CAPES, Plataform a Sucupira (cf. nota 1).

\footnotetext{
* Programas de Pós-Graduação em Ciência(s) da(s) Religião(s), 2018. 